\title{
PENGHIBURAN DALAM RUANG KESENDIRIAN
}

\author{
Gita Atika1), Suwandi Supatra ${ }^{2)}$ \\ 1)Program Studi S1 Arsitektur, Fakultas Teknik, Universitas Tarumanagara, gitaatika@yahoo.co.id \\ 2)Program Studi S1 Arsitektur, Fakultas Teknik, Universitas Tarumanagara, ybhan50@gmail.com
}

\begin{abstract}
Abstrak
Pada tahun 2020, Virus Corona menyita perhatian dunia. Berbagai macam bidang terkena dampak oleh pandemi Covid-19, hingga mempengaruhi kesehatan mental masyarakat baik yang terkena atau yang tidak. Fenomena yang dialami manusia pada pandemi ini semacam detachment atau penghapusan dari kenyataan. Kondisi depression, anxiety, aggression, poor self-esteem, stress dan penurunan sexual arousal, gejala-gejala tersebut merupakan kondisi mood negatif (Negative Mood) dan hal ini tidak baik bila tidak ada penanganan. Judul perancangan yang akan dibahas yaitu Penghiburan dalam Ruangan Kesendirian. Untuk meningkatkan suasana hati yang rendah perlu perubahan kecil dalam kehidupan diri yaitu dengan ruang kesendirian. Dalam kesendirian, orang memutuskan koneksi ke luar dan terhubung ke internal. Pola pikir ini tampaknya memicu kreativitas dan kekuatan batin seseorang, hal ini membantu orang mengenal diri sendiri lebih baik dan memetakan kehidupannya dengan cara yang otentik. Kesendirian berpotensi sebagai jawaban pada keadaan mood negatif. Metode yang digunakan dalam perancangan ini adalah cognitivestyle dan pendekatan salutogenic yang menerjemahkan Lima Panca Indra dengan Dwelling sebagai konsep pada perancangan dan menghasilkan area kesendirian melalui Lima Panca Indra. Lokasi berada di area dekat dengan universitas, yaitu Universitas Mandiri Daan Mogot, dikarenakan mahasiswa memiliki tingkat depresi dan kecemasan paling tinggi. Proyek terdapat di 2 tapak yang bersebelahan dengan pembagian fungsi hunian dan paviliun. Hunian sebagai tempat area kesendirian dengan zonasi privat dan paviliun sebagai penunjang area kesendirian dengan zonasi umum.
\end{abstract}

\section{Kata kunci: Kesendirian; Lima Panca Indra; Mood Negatif}

\begin{abstract}
In 2020, the Corona Virus is attracting the world's attention. Various fields have been affected by the Covid-19 pandemic, thus affecting the mental health of people who are affected or not. The phenomenon that humans experience in this pandemic is a kind of detachment or removal from reality. Depression, anxiety, aggression, poor self-esteem, stress and decreased sexual arousal, these symptoms are negative mood conditions and this is not good if there is no treatment. The title of the design that will be discussed is Solace in Solitude Space. To improve a low mood requires small changes in one's own life, namely the solitude space. In solitude, people disconnect from the outside and connect to the internal. This mindset seems to spark creativity and inner strength, it helps people get to know themselves better and map their lives in an authentic way. Solitude has the potential as an answer to negative mood states. The method used in this design is cognitive-style and salutogenic approach which translates the Five Senses with Dwelling as a concept in design and produces an area of solitude through the Five Senses. The location was in an area close to the university, namely Daan Mogot Mandiri University, because students had the highest levels of depression and anxiety. The project is located on 2 sites adjacent to the distribution of residential and pavilion functions. Residential as a solitude area with private zoning and pavilions as supporting solitude areas with general zoning.
\end{abstract}

\section{Keywords: Lima Panca Indra; Negative Mood; Solitude}




\section{PENDAHULUAN}

\section{Latar Belakang}

Dengan adanya perubahan cara berinteraksi orang sesama orang, maupun makhluk hidup lainnya, sosialisasi pun berubah. Istilah quarantine dan isolation ada di mana-mana, dari berbagai macam masalah muncul istilah yang sering dibincangkan yaitu social distancing. Social distancing berasal dari epidemiologi dan itu berarti bahwa orang harus tinggal cukup jauh satu sama lain untuk membatasi penyebaran virus dari satu orang ke orang lain. Tetapi social distancing tidak berarti tidak bersosialisasi, sosialisasi masih bisa dilakukan dengan jarak secara fisik tidak dekat. Manusia adalah makhluk sosial, manusia membutuhkan orang lain untuk bertahan hidup.

Kata numbness terus terdengar, bukan sakit tapi lebih merasa tidak nyaman. Fenomena yang dialami manusia pada pandemi ini semacam detachment atau penghapusan dari kenyataan. Para ahli mengatakan, pandemi kali ini memberikan dampak negatif yang sangat signifikan pada kesehatan mental. Depression, anxiety, aggression, poor self-esteem, stress dan penurunan sexual arousal, gejalagejala tersebut merupakan kondisi mood negatif (Negative Mood) dan hal ini tidak baik untuk kesehatan psikologi manusia bila tidak ada penanganan. Walau kebanyakan orang tangguh (resilience) setelah bencana dan hanya sebagian kecil yang mengalami kondisi kronis tetapi hal tersebut tetap terjadi, terus ada dan berpengaruh kepada orang-orang. Seseorang yang mengalami atau tidak mengalami bencana pun juga memiliki mood negatif akibat dari sosialisasi dan masyarakat. Permasalah ini akan terus menerus ada dan gejala mood negatif akan selalu menyerang.

Terdapat tempat seperti 'rehabilitas' tetapi tempat tersebut hanya untuk orang dengan kesehatan mental pada tingkat 'mental disorder'. Tidak ada tempat pemulihan untuk orang-orang dengan tingkat 'rendah' atau 'affect' pada kesehatan mental. Tempat rehabilitas mental juga kerap dipersamakan dengan hal tidak bagus menurut pandangan masyarakat. Pada intinya, tidak ada zona nyaman untuk menyembuhkan mental diri sendiri di luar dari private space. Lalu bagaimana caranya manusia dapat bisa bertahan hidup walau mengalami sulitnya bersosialisasi, hal ini dapat dijawab oleh ciri-ciri perilaku manusia. Karakteristik dari sebuah tempat tinggal memiliki kecenderungan terhadap sifat dan kepribadian penghuni. Kepribadian dari penghuni dapat dijadikan cara mendesain sebuah tempat untuk kondisi sekarang dan kedepannya. Menurut orang-orang kenyamanan dan keamanan adalah yang terpenting untuk mereka. Karena adanya berbagai macam kepribadian dan cenderung terjadinya perubahan pada manusia, sebuah tempat tinggal akan mengambil ciri-ciri kepribadian yang cocok untuk situasi penghuni sekarang dan menyesuaikannya.

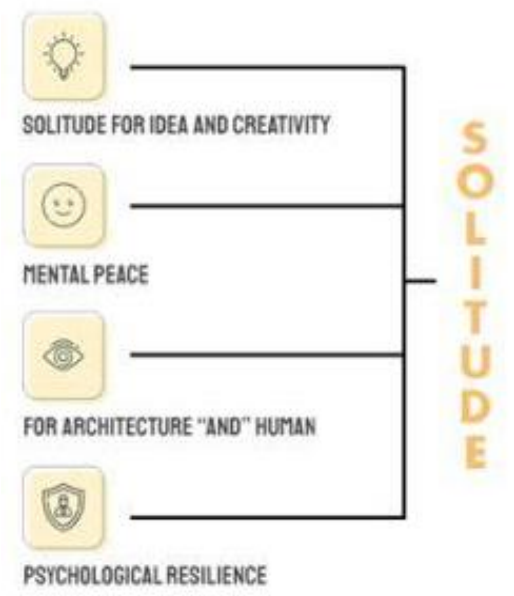

Gambar 1. Pandangan solitude pada proyek Sumber: Penulis, 2020 


\section{Rumusan Permasalahan}

Kebanyakan orang terkadang merasa sedih, tetapi hal ini mempengaruhi kehidupan. Dalam psikologi, mood atau suasana hati adalah keadaan afektif. Berbeda dengan emosi atau perasaan, suasana hati kurang spesifik, kurang intens, dan kecil kemungkinannya untuk diprovokasi atau dipakai oleh stimulus atau peristiwa tertentu. Suasana hati biasanya digambarkan memiliki valensi positif atau negatif. Dengan kata lain, orang biasanya berbicara tentang suasana hati yang baik (good mood) atau suasana hati yang buruk (bad mood). Bad Mood memiliki tingkatan yang berbeda-beda, dari yang ringan hingga yang parah.

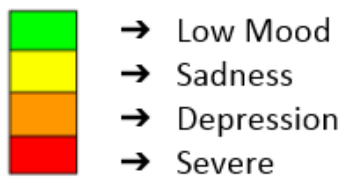

Gambar 2. Tingkatan mood negatif Sumber: Penulis, 2020

Dari tingkatan tersebut, mulai dari depression hingga ke paling parah memiliki pengobatan yang tersedia atau secara alternatif, namun bagaimana dengan tingkat dibawah itu. Walau kondisi ini tidak buruk tetapi awal dan dasar dari tingkat parah berasal dari tingkat ringan itu. Terutama untuk low mood dan sadness yang biasanya hanya bisa memperbaiki hal tersebut dengan melakukannya secara sendiri (self-improve), untuk meningkatkan suasana hati yang rendah perlu perubahan kecil dalam kehidupan diri.

Tempat rehabilitasi mental kerap dideskripsikan sebagai sesuatu yang buruk menurut pandangan masyarakat. Secara umum, semua orang cenderung ingin memiliki aspirasi hidup yang sama dengan masyarakat atau budaya masing-masing. Mereka ingin dihormati sebagai individu yang otonom dan menjalani hidup senormal mungkin. Karena itu, kebanyakan orang yang mengalami depresi dan kecemasan enggan untuk mendapatkan konsultasi atau pergi ke tempat rehabilitasi mental.

\section{Tujuan}

Manfaat proyek yang dirancang untuk merubah pandangan modern architecture yang memprioritaskan keamanaan, fungsi dan sebagainya - yang semuanya adalah penting, tetapi tidak cukup untuk sustainability karena mengabaikan manusia secara psikologis dan budaya. Maka dari itu, diberikan tempat yang akan mendorong aspek-aspek kurang tersebut. Dengan membuat bangunan dengan desain yang berfokus terhadap kekurangan aspek-aspek tersebut. Lalu proyek juga dirancang untuk mendorong dan mendukung psychological resilience pengunjung serta memberikan kenyamanan terutama untuk mahasiswa karena stress akibat studi dan hidup mandiri.

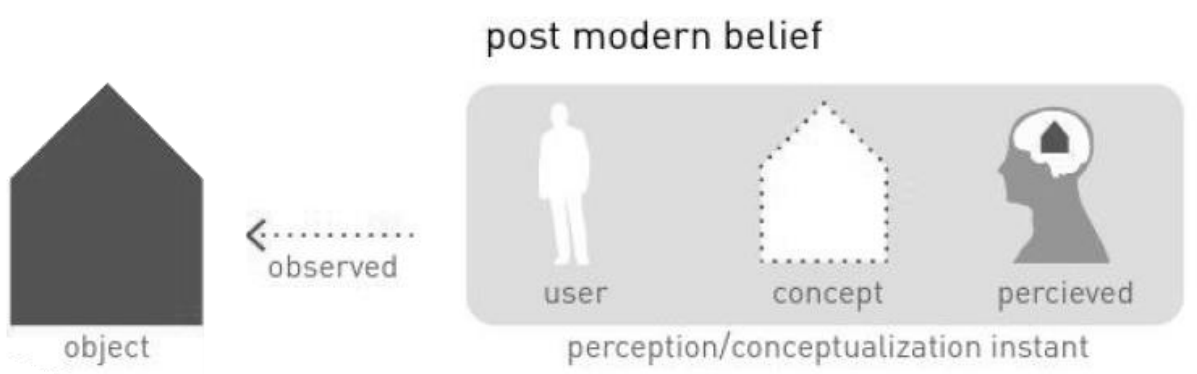

Gambar 3. Pandangan arsitektur modern Sumber: TMD Studio, 2017 


\section{KAJIAN TEORITIS}

Dari segi literal, "Dwelling" berarti "to dwell". Dalam bahasa Denmark, "dwell" atau "dvæle" berarti untuk tetap atau tinggal di tempat lebih lama dari biasanya atau diharapkan. Lalu dalam bahasa Swedia, "dwell" atau "dväljas" berarti tinggal, atau dalam arti lain, memiliki tempat permanen. Sedangkan kata dari "hunian", artinya tindakan atau fakta menempati suatu tempat. Seluruh arti dari makna bahasa-bahasa tersebut memiliki hubungan dan korelasi antara "tempat" dan "tinggal".

Sama dengan para ahli arsitek yang memiliki pendapat yang berbeda-beda, tetapi inti dari makna tersebut tetap sama. Dwelling adalah tetap di tempat, dan untuk ditempatkan dalam hubungan tertentu dengan keberadaan, suatu hubungan yang ditandai dengan pemeliharaan, memungkinkan dunia menjadi apa adanya (Heidegger, 1999). Menurut Heidegger (1999) karakter dasar dari Dwelling adalah untuk meluangkan, untuk mempertahankan... Dwelling itu sendiri adalah selalu tinggal dengan hal-hal. Dwelling, sebagai pelestarian, menjaga empat ruas yang dengan mana makhluk hidup tetap dalam berbagai hal. Dalam karyanya "Building, Dwelling, Thinking", ia menegaskan bahwa pemikiran dan puisi adalah kebutuhan untuk berdiam.

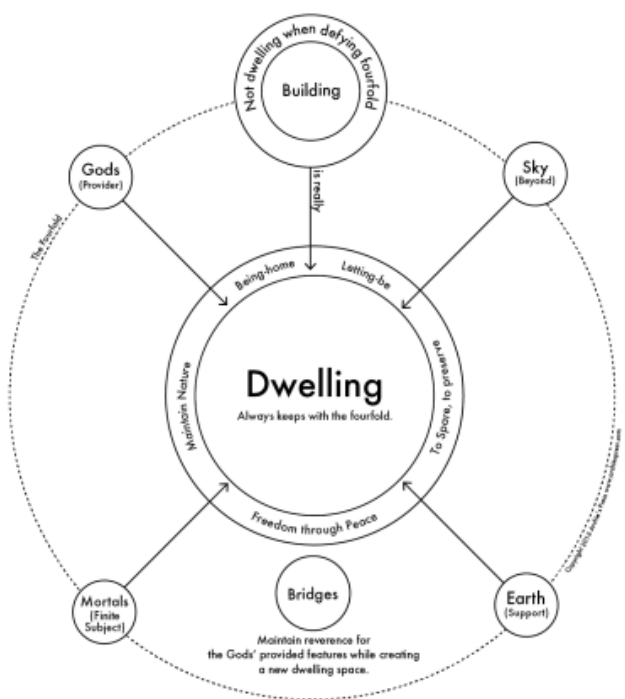

Gambar 4. Skema parameter Dwelling menurut Heidegger Sumber: Medium.com

Lalu oleh Christian Norberg-Schulz dalam bukunya "The Concept of Dwelling", Dwelling untuk manusia, lebih dari sekadar memiliki atap di atas kepala kita dan sejumlah meter persegi yang dapat kita gunakan. Pertama, berarti bertemu orang lain untuk bertukar produk, ide, dan perasaan, yaitu mengalami hidup sebagai banyak kemungkinan. Kedua, berarti mencapai kesepakatan dengan orang lain, yaitu menerima seperangkat nilai bersama. Terakhir, yaitu menjadi diri sendiri, dalam arti memiliki dunia kecil yang dipilih kita sendiri. Dapat disebut mode ini tempat tinggal kolektif, publik dan pribadi. Dari apa yang dikatakan Schulz, dapat dipahami bahwa menemukan identifikasi manusiawi adalah kunci dan makna dari Dwelling tersebut. Membuat hubungan yang bermakna dengan dunia yang dikompromikan dari berbagi hal-hal yang bergantung pada bentuk material suatu tempat, aspek ganda dari Dwelling adalah penemuan identitas dan penentuan lokalitas.

\section{METODE DESAIN}

Gaya berpikir yang beda atau cognitive style, yaitu gaya berpikir dipadukan dengan hakikat pengambilan keputusan manusia, yang didasarkan pada heuristik daripada logika. Pengambilan keputusan heuristik menggunakan jalan pintas dalam kekuatan proses mental, biasanya disebut rulesof-thumb, trial-and-error, tebakan cerdas, atau akal sehat. 


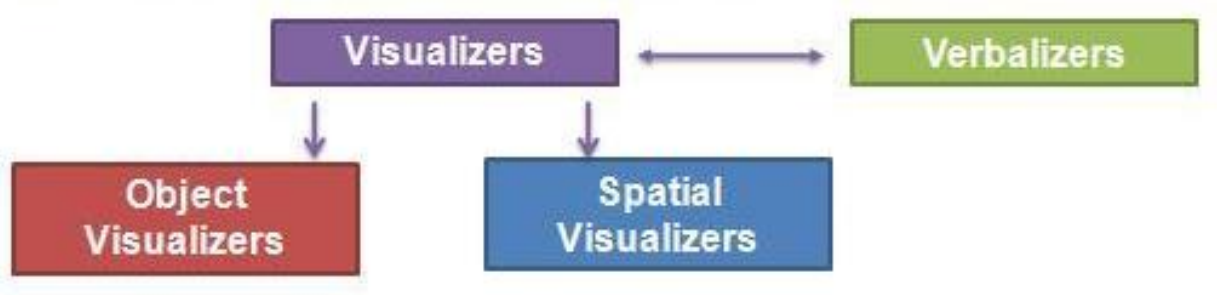

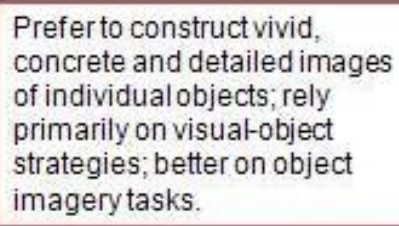

Prefer to schematically represent spatial relations of objeds and spatial transformations; rely primarily on visual-spatial strategies; better on spatial imagery tasks.
Prefer to process and representinformation verbally; rely primarily on verbal-analytical, nonvisual strategies; better on verbal tasks.

Gambar 5. Skema cognitive-style Sumber: Maria Kozhevnikov's Lab, 2005

Lalu pendekatan Salutogenic untuk desain, teori oleh Aaron Antonovsky yang berfokus pada faktorfaktor yang mendukung kesehatan manusia. Salutogenic dalam arsitektur adalah mensimulasikan pemulihan alami kesehatan melalui rangsangan psikologis. Desain harus meningkatkan kemampuan penanganan, kelengkapan, dan kebermaknaan hidup pengunjung. Ini harus mencakup sirkulasi yang baik, ruang terbuka, taman penyembuhan, dll.

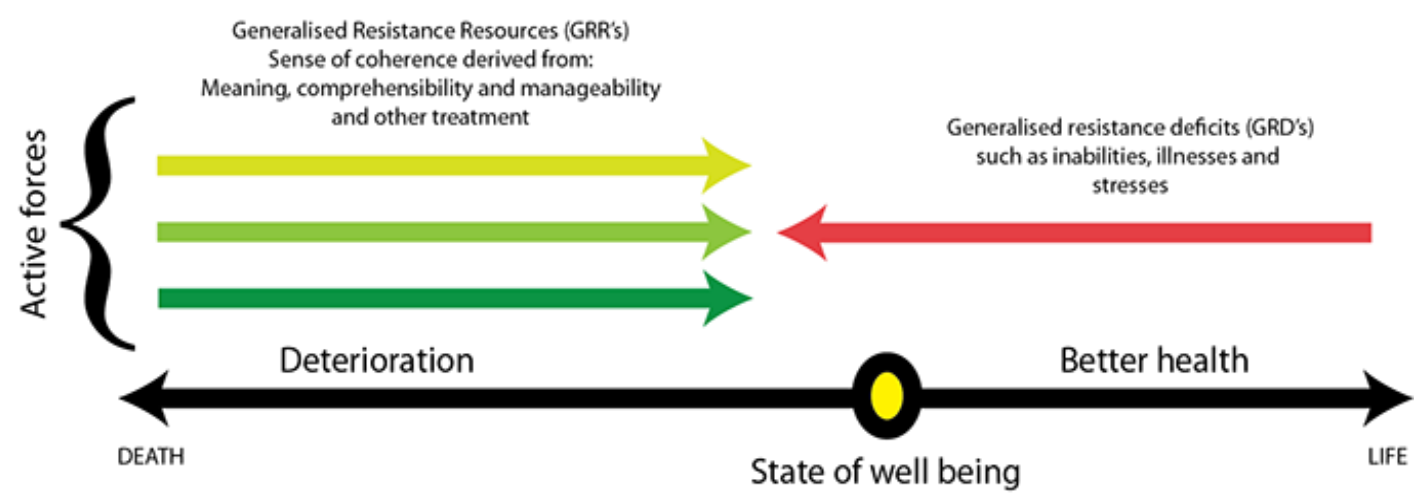

Gambar 6. Efek dan pendekatan Salutogenic pada desain Sumber: Psychological Design

Tata letak furnitur dapat menjadi faktor penting dalam perancangan untuk mendiversifikasi ruang yang dirancang dan memberikan pilihan bagi pasien untuk memutuskan antara interaksi sosial atau kesendirian tergantung pada keadaan atau keadaan pikiran. Desain harus menggabungkan bahan, tekstur, warna, dan ruang berbeda yang menargetkan kelima indra manusia memberikan pengalaman sensorik.

\section{DISKUSI DAN HASIL \\ Profil Tapak}

Menempati lahan seluas 4 hektar, akan di bangung kawasan untuk kampus Mandiri University. Kampus ini dimaksudkan untuk mengantisipasi kemungkinan derasnya kedatangan bankir-bankir asing dari kawasan ASEAN. Kompleks tersebut akan menyediakan fasilitas pembelajaran yang terintegrasi, termasuk asrama, laboratorium keuangan, serta sarana sosial dan olahraga, bagi karyawan Mandiri Group dan lembaga keuangan diluar Mandiri Group. Sekitar kampus direncanakan untuk dibangunnya perumahan dan apartemen untuk pegawai. Tujuan pembangunan tempat ini agar para pegawai Bank Mandiri dapat tinggal di tengah kota sehingga perjalanan untuk mencapai tempat kerja terpangkas. 
Hal ini diharapkan dapat meningkatkan produktif dari Bank Mandiri. Saat ini kawasan kompleks masih dalam progress pembangunan dan perancangan.

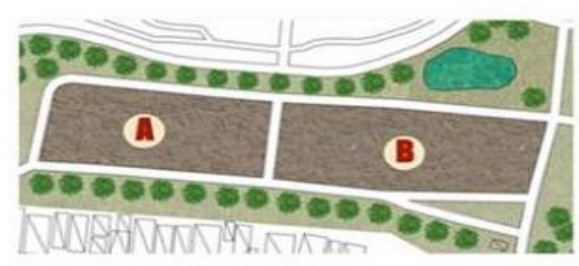

Peruntukan
KDB : 60
$K \mathrm{~KB}: 1,2$
$\mathrm{~KB}: 2$
$\mathrm{KDH}: 20$
$\mathrm{KTB}:-$

\begin{tabular}{rl|} 
Luas tapak & $=(A+B)$ \\
& $=4.200+5.000$ \\
& $= \pm 9.200 \mathrm{~m}^{2}$ \\
& \\
IAPAK & IAPAK $B$ \\
KOB $: 2.520 \mathrm{~m}^{2}$ & KDB $=3.000 \mathrm{~m}^{2}$ \\
KLB $: 5.040 \mathrm{~m}^{2}$ & KLB $=6.000 \mathrm{~m}^{2}$ \\
KB $: 2$ Lantai $^{2}$ & KB $=2$ Lantai \\
KOH $: 840 \mathrm{~m}^{2}$ & KDH $: 1.000 \mathrm{~m}^{2}$ \\
KTB $:-$ & KTB $:-$ \\
\hline
\end{tabular}

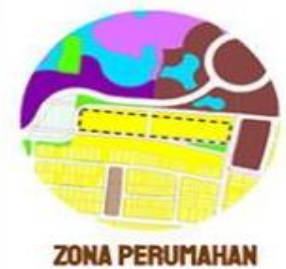

Gambar 7. Peruntukan tapak proyek Sumber: Dokumentasi Pribadi

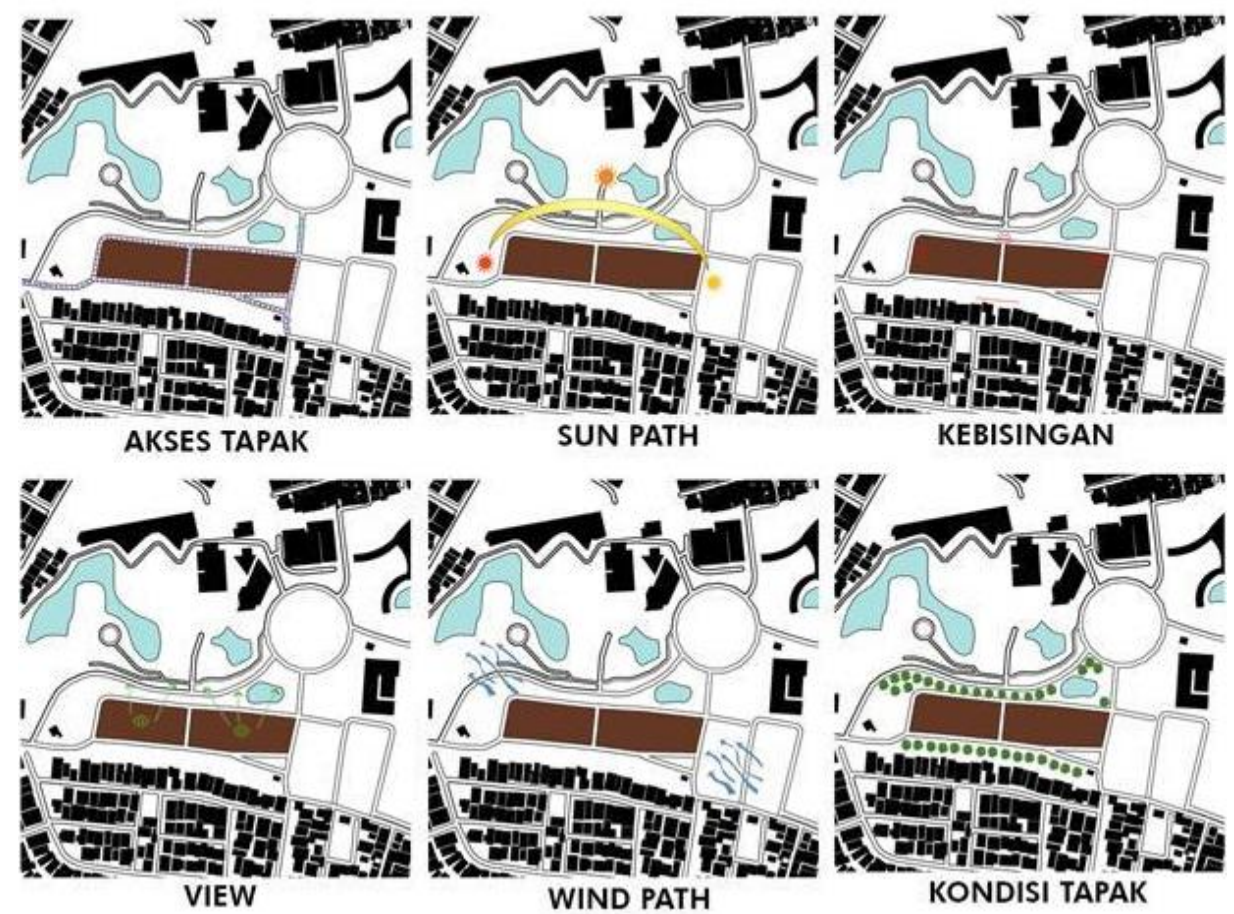

Gambar 8. Analisis tapak di Mandiri University Daan Mogot Sumber: Penulis, 2020

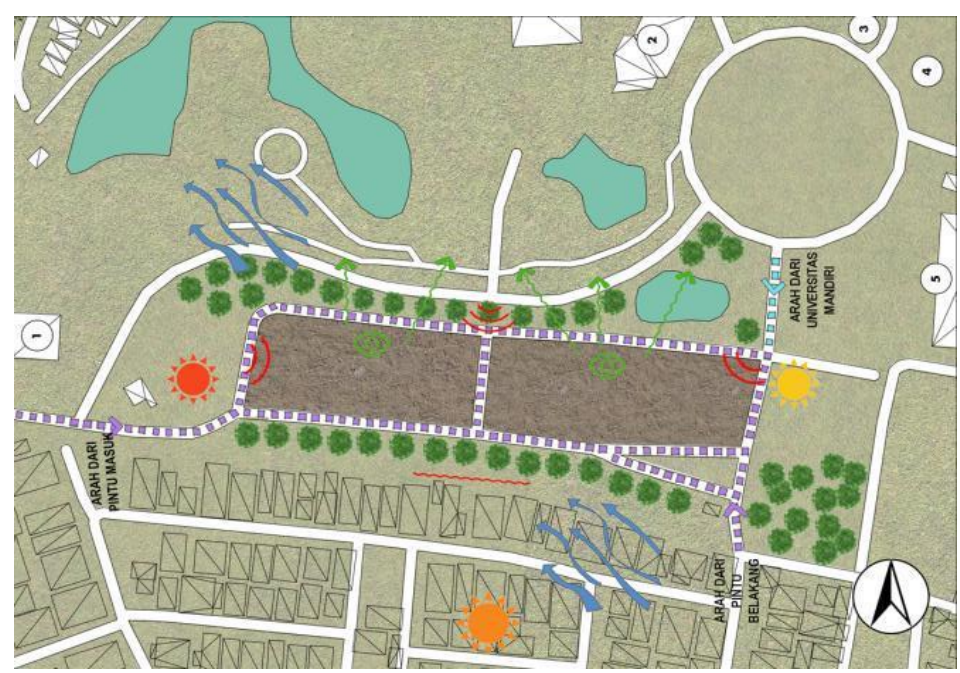

Gambar 9. Analisis tapak proyek Sumber: Penulis, 2020 


\section{Program}

Penentuan program ruang dan fungsi ditentukan oleh metode desain yang ditentukan. Dengan penggunaan Alegori Lima Panca Indra, pengertian Dwelling dengan 5 indra akan dihubungkan secara spasial dan menghasilkan fungsi dan program bangunan. Setiap fungsi pada bangunan diberikan peran salah satu dari 5 indra.

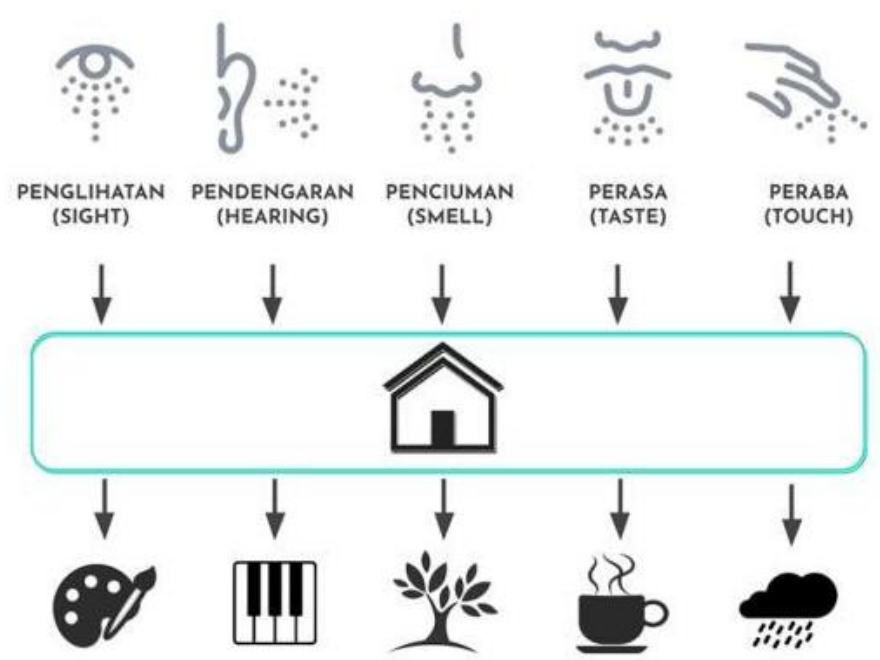

Gambar 10. Penerjemahan Lima Indera dengan Dwelling

Sumber: Penulis, 2020

\section{Konsep}

Peletakan masing-masing fungsi diutamakan pada proyek, untuk mendapatkan tingkat privasi yang tinggi pada para pengguna yang ingin sendiri. Akses dan alur akan dibuat dalam bentuk berurutan, masing-masing fungsi tidak dapat mengganggu area-area yang memiliki tingkat privasi lebih tinggi darinya. Tidak seluruh fungsi mendapatkan privasi yang tinggi, rata-rata fungsi akan dibuat publik tetapi pengguna dapat memilih untuk lebih terbuka dengan orang lain atau memisahkan diri dari orang lain.

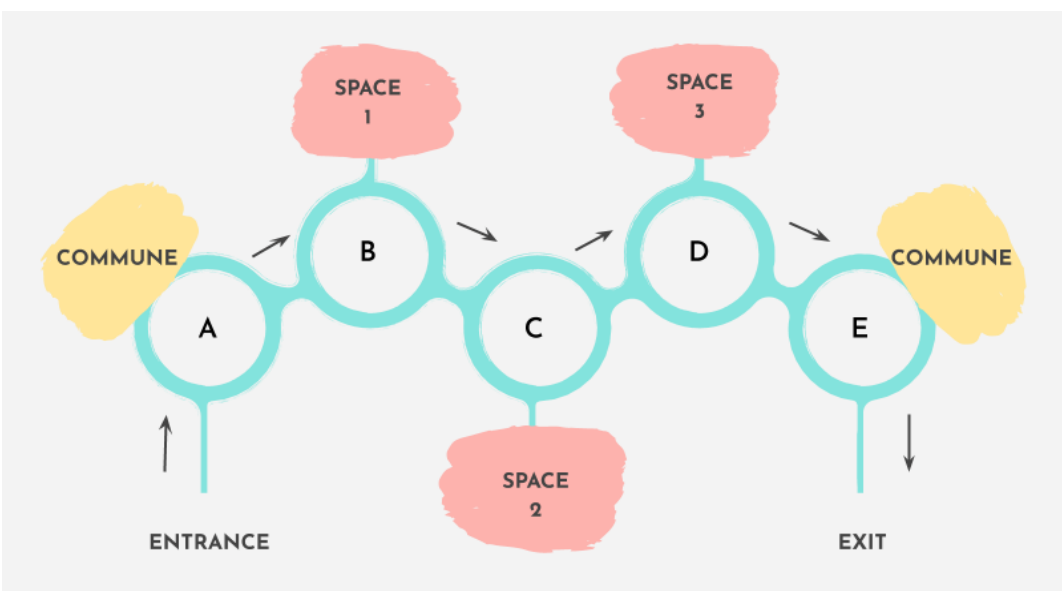

Gambar 11. Skema Alur Program Ruang Sumber: Penulis, 2020

\section{Deskripsi Desain}

Penggunaan tema 5 panca indra pada fungsi paviliun yang bersifat publik dan mendalam, sedangkan untuk fungsi hunian akan dibuat bersifat privat dan tertutup. Setiap fungsi dalam paviliun memiliki salah satu dari tema " 5 panca indra" seperti pada gambar di bawah. Tema pada gambar di bawah berfokus pada indra penglihatan dengan media karya seni seperti lukisan, patung, dan pemandangan lanskap. Penggunaan cahaya pada ruangan juga mendorong sensorik indra penglihatan, dengan 
memberikan area yang paling gelap yaitu black room di paling dalam bangunan.

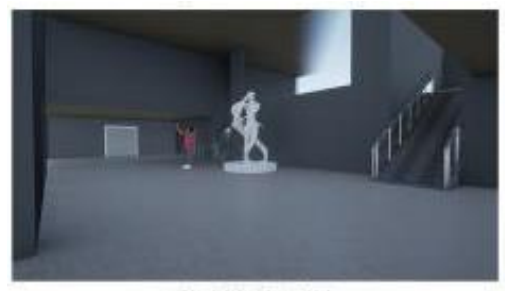

GALERI SENI

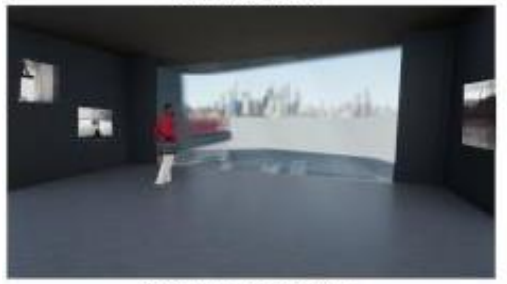

SOLITUDE SPACE

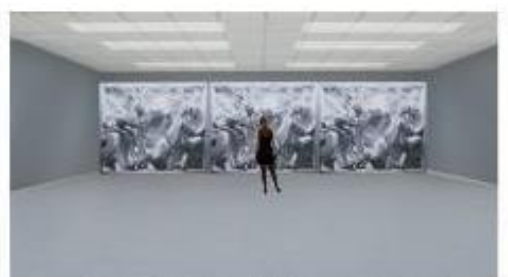

BOSPHORUS SCULPTOR ROOM

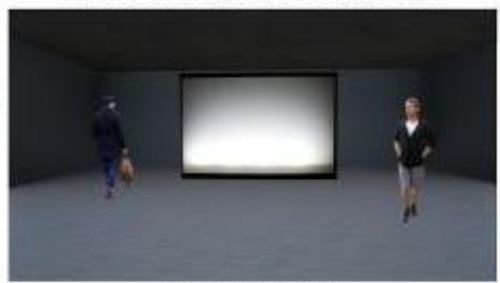

BLACK ROOM

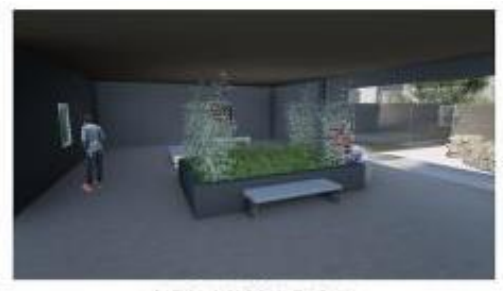

SCENERY ROOM

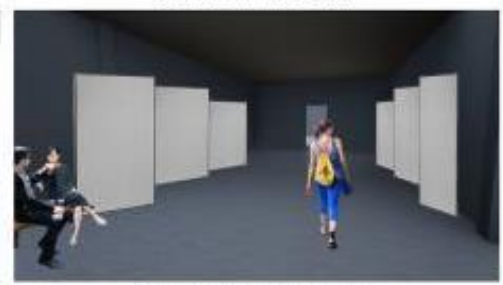

THEMATIC ROOM

Gambar 12. Ruang dalam bangunan paviliun

Sumber: Penulis, 2020

Ruang pada lantai 2 merupakan area thematic room yang merepresentasikan tema panca indra "pendengaran" dan "peraba". Sebuah tempat dengan tema masing-masing yang berbeda, mencerminkan kepribadian dan karakteristik dari seluruh desainer ruang tersebut dengan penggunaan warna dan komposisi dalam penataan. Untuk 3 panca indra lainnya berada di luar galeri seni. Setelah masuk ke bangunan dan jalan menerus melewati lobi, area ruin valley terlihat. Area ruin valley menggunakan panca indra "penciuman" yang terinspirasi dari bau karya seni reruntuhan yang memberikan kesan bau "tanah". Bau tanah dapat mengingatkan pengunjung terhadap emosional tertentu. Area selanjutnya setelah ruin valley yaitu rest area outdoor, area di mana pengunjung dapat merasakan panca indra "peraba". Pada area ini pengunjung dapat merasakan 2 macam "peraba", tipe pertama yang dialami dari cahaya matahari yang mempengaruhi hawa pengunjung dan tipe kedua yaitu saat hujan air akan mengalir turun dari lobang atap ke bawah area yang sudah ditanami bunga dan rerumputan, pengunjung dapat mencoba menyentuh aliran air yang turun sebagai "peraba". Lalu untuk area terakhir yaitu kafe yang berfungsi sebagai tema panca indra "perasa" dan "penciuman" dengan kopi sebagai bahan utama atau khas kafe tersebut.

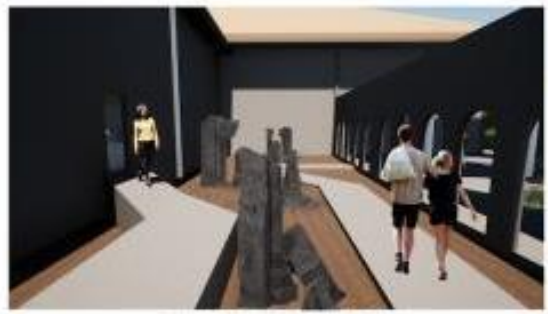

RUIN VALLEY

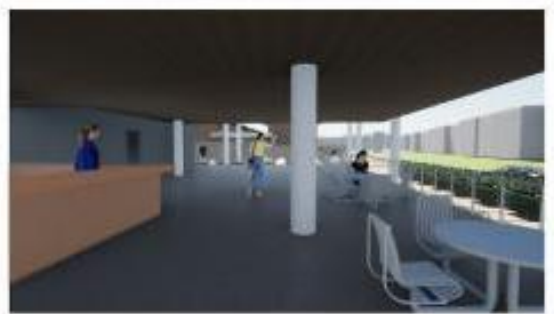

KAFE

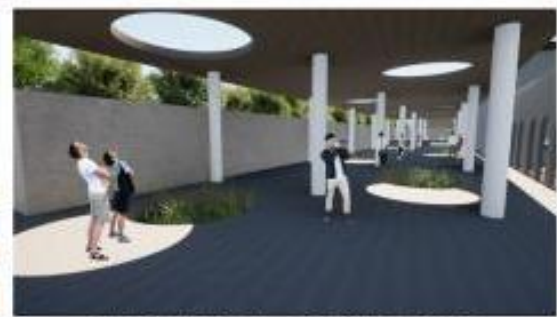

REST AREA OUTDOOR

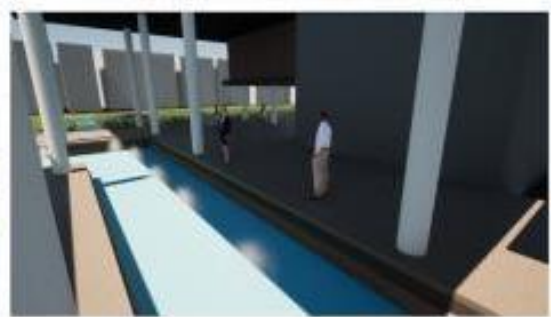

REST AREA OUTDOOR

Gambar 13. Area luar dalam bangunan paviliun

Sumber: Penulis, 2020 


\section{KESIMPULAN DAN SARAN \\ Kesimpulan}

Merasa kesepian tidak sama dengan kesendirian (solitude). Manusia bisa kesepian tetapi tidak sendirian, dan bisa sendiri tetapi tidak kesepian. Kesendirian (solitude) adalah kondisi konstruktif dalam keterlibatan dengan diri sendiri. Waktu yang direncanakan dan dihabiskan sendirian untuk melepaskan diri dari gangguan, untuk berpikir dan melakukan dan menjadi seperti yang diinginkan tidak sama dengan kesepian. Tetapi ketika seseorang kehilangan semua akal tentang cara menyambung kembali dan menarik diri dalam lingkaran yang melelahkan, orang tersebut dapat dengan mudah terjebak dalam epidemi kesepian. Dalam kesendirian (solitude), orang memutuskan koneksi ke luar dan terhubung ke internal. Hal itu adalah sikap atau pola pikir yang tampaknya memicu kreativitas dan kekuatan batin seseorang. Ini membantu orang mengenal diri sendiri lebih baik dan memetakan kehidupannya dengan cara yang otentik. Mungkin itu adalah sikap, mungkin itu adalah pola pikir, mungkin itu adalah tujuan. Yang diketahui adalah bahwa orang menginginkan hal tersebut akhir-akhir ini. Bahkan jika dipaksa, orang tersebut dapat menemukan kepuasan dalam kesendirian. Kesendirian (solitude) berpotensi sebagai jawaban pada keadaan mood negatif.

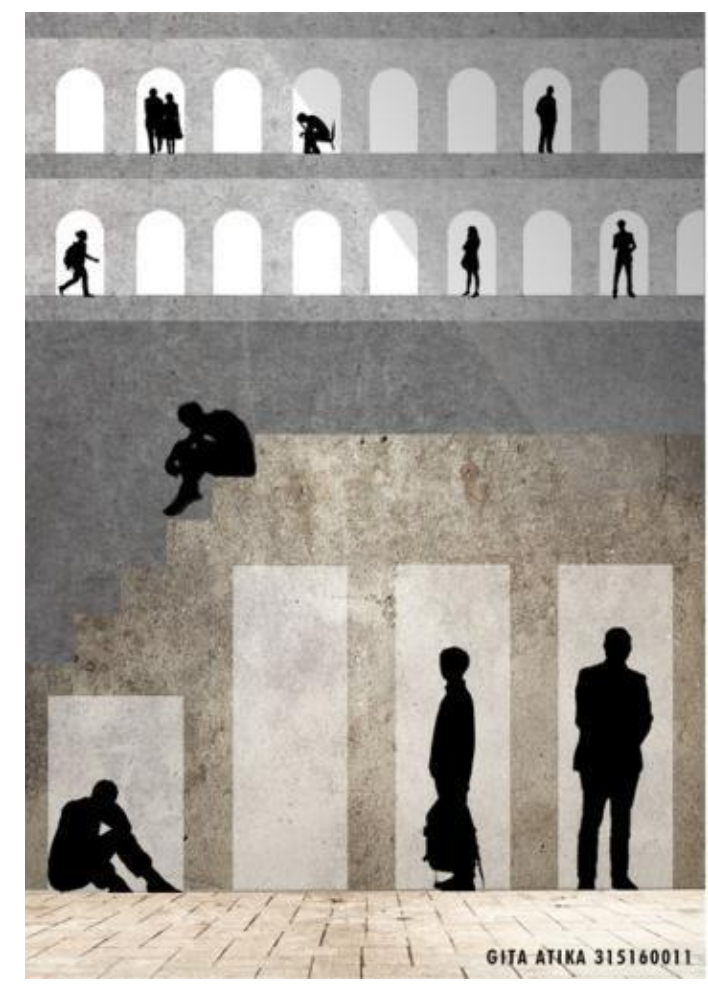

Gambar 14. Ilustrasi mengenai Dwelling Sumber: Penulis, 2020

Dengan penggunaan tema Lima Panca Indra pada perancangan dan pengertian mengenai Dwelling, tempat khusus dirancang dimana pengunjung dapat merasa santai dan nyaman. Hal ini memberi pengunjung rasa kendali karena mereka bertanggung jawab atas pengalaman yang dibuat untuk mereka sendiri yang memulai dan mengendalikan tindakan. Hal ini dicapai melalui penggunaan Lima Panca Indra pada setiap ruangan. Suara khusus dan efek visual, pengalaman haptik, getaran, penggunaan aroma dan musik yang menenangkan, baik secara mandiri atau bersamaan. Perancangan ini berfokus agar orang menikmati berbagai pengalaman untuk terapi, pembelajaran, stimulasi, relaksasi, dan kesenangan. Integrasi antara fungsi paviliun dan hunian, membuat tempat menjadi sebuah area mandiri. Proyek juga dapat terintegrasi dengan Mandiri University yang memiliki segala macam fasilitas, untuk para pekerja atau mahasiswa yang tidak ingin keramaian dapat pergi ke proyek 
dan menikmati ketenangan oleh kesendirian.

\section{Saran}

Diharapkan proyek "Penghiburan dalam Ruang Kesendirian" dapat membantu orang-orang mendapatkan stabilitas pikiran dan menambahkan mental peace untuk generasi sekarang dan kedepannya yang terkena bencana maupun tidak dengan mendesain sebuah bangunan terbuka yang dapat dikunjungi berbagai macam kalangan terutama remaja serta menciptakan lingkungan dimana pengunjung dapat diberikan kebebasan memilih untuk bersosialisasi atau untuk menyendiri. Kedepannya, diharapkan proyek yang berfokus untuk memberikan Solitude Space ini dapat menjadi sebuah tempat seseorang dapat beristirahat dengan tenang.

\section{REFERENSI}

Bachelard, G. (2014). The Poetics of Space. London: Penguin Books Ltd.

Deci, E L. \& Ryan, R., M. (2008). Hedonia, Eudaimonia, and Wellbeing: An Introduction. Journal of Happiness Studies, 9:1-11, DOI 10.1007/s10902-006-9018-1, http://www.preptheday.com/uploads/1/2/0/0/120050120/hedonia_eudaimonia_and_wellbeing.pdf

Golembiewski, J. A. (2016) Salutogenic Architecture in Healthcare Settings, diunduh 2020, https://www.ncbi.nlm.nih.gov/books/NBK435851/

Heidegger, M. (1971). Poetry, Language, Thought. New York: Harper \& Row.

Heidegger, M. (1999). Building, Dwelling, Thinking. In David Farrell Krell (Ed.), Basic Writings Martin Heidegger (pp. 347-363). London: Routledge.

Jormakka, K. (2008). Basic Design Methods. New York: McGraw Hill, Inc.

Lehrer, J. (2011). The Psychology of Architecture. https://www.wired.com/2011/04/the-psychologyof-architecture/

Makhno, S. (2020). Life after coronavirus: how will the pandemic affect our homes. https://www.dezeen.com/2020/03/25/life-after-coronavirus-impact-homes-designarchitecture/

Norberg-Schulz, C. (1985). The Concept of Dwelling: On the way to figurative architecture. New York: Rizzoli International Publications, Inc.

Pallasmaa, J. (2012). The Eyes of the Skin : Architecture and the Senses. New York: John Wiley \& Sons Inc.

Tanizaki, J. (2006). In Praise of Shadows. London: Vintage Publishing

Zumthor, P. (2010). Thinking Architecture. Basel: Birkhauser 